\title{
Modestobacter multiseptatus gen. nov., sp. nov., a budding actinomycete from soils of the Asgard Range (Transantarctic Mountains)
}

\author{
Udo Mevs, ${ }^{1}$ Erko Stackebrandt, ${ }^{2}$ Peter Schumann, ${ }^{2}$ \\ Claudia A. Gallikowski ${ }^{3}$ and Peter Hirsch ${ }^{1}$
}

1 Institut für Allgemeine Mikrobiologie, Universität Kiel, D-24118 Kiel, Germany

2 DSMZ - Deutsche Sammlung von Mikroorganismen und Zellkulturen, D-38124 Braunschweig, Germany

3 Hessisches Ministerium für Umwelt, Energie, Jugend, Familie u. Gesundheit D-65189 Wiesbaden, Germany

Author for correspondence: Peter Hirsch. Tel: +49 431880 4340. Fax: +49431880 2194. e-mail: phirsch@ifam.uni-kiel.de

Oligotrophic PYGV medium, inoculated with soils from Linnaeus Terrace (1600 $\mathrm{m}$, Antarctica), yielded four aerobic actinomycetes with short rods, multiple and irregular septa and often motile buds. Cells were 1.0-2.8 $\times 1.0-3.0 \mu \mathrm{m}$ and colonies were beige to pink. The isolates were nearly identical in physiological and biochemical tests. Three strains grew from $0{ }^{\circ} \mathrm{C}$ to $25-28{ }^{\circ} \mathrm{C}$, but one was psychrophilic with a maximum growth temperature of $20^{\circ} \mathrm{C}$. Carbon sources utilized were D-glucose, D-galactose, lactose, sucrose or mannitol; malate, succinate, fumarate, pyruvate or glutarate were decarboxylated aerobically. Peptone and yeast extract were the preferred nitrogen sources. Nitrate was reduced aerobically or anaerobically. Cell walls contained mesodiaminopimelic acid, glutamate, alanine, glycine, galactose, glucose and ribose. Major fatty acids of strains AA-802, $-824,-825$ and $-826^{\top}$ were $n 18: 1$, 116:0 and ai17:0. Major respiratory quinones were $M K-9\left(H_{4}\right)$ and $M K-8\left(H_{4}\right)$. Polar lipids were diphosphatidylglycerol, phosphatidylethanolamine and phosphatidylinositol. Phosphatidylglycerol was found in most strains. The DNA G+C contents were 68-70 mol\%. In 16S rDNA analyses, similarity values obtained for 500 nucleotides from the $5^{\prime}$ terminus were $>99.5 \%$. Almost complete sequences from AA-826 ${ }^{\top}$ and -825 were $99.9 \%$ similar. Strain AA-826 ${ }^{\top}$ belonged to a novel cluster of desert soil and rock isolates within the Geodermatophilaceae and was equidistantly related to members of Geodermatophilus and to a Blastococcus lineage. The four isolates represent a new genus, Modestobacter gen. nov., with Modestobacter multiseptatus sp. nov. as the type species. The type strain, Modestobacter multiseptatus AA-826', was deposited in the DSMZ as DSM $44406^{\top}$

Keywords: Modestobacter, budding bacteria, actinomycetes, Antarctic soils

\section{INTRODUCTION}

The ice-free McMurdo Dry Valleys of Antarctica cover a region of about $7000 \mathrm{~km}^{2}$ and consist of alternating mountain ranges and glacial valleys. This area has all the characteristics of a hostile, dry and cold desert (Nienow \& Friedmann, 1993). The relative humidity is low, and small amounts of snow, which rarely fall, melt quickly into soils and rocks or are rapidly blown away. Soil-forming processes are extremely slow, and fine-granular soil material often

The GenBank/EMBL accession number for the 165 rDNA sequence of Modestobacter multiseptatus AA-826 ${ }^{\top}$ is $\mathrm{Y} 18646$. collects locally when blown around by wind and must be considered as regolithic because it is almost devoid of organic components. Summer temperatures normally vary between $-15^{\circ} \mathrm{C}$ and $0{ }^{\circ} \mathrm{C}$, and winter temperatures can drop as far down as $-60^{\circ} \mathrm{C}$ (Friedmann, 1980). However, some conditions allowing for microbial growth do exist in special locations: McKay \& Friedmann (1985) found summer temperatures underneath sandstone surfaces reaching $+17 \cdot 3{ }^{\circ} \mathrm{C}$, and Behling (1971) observed soil surface temperatures exceeding $+20^{\circ} \mathrm{C}$.

For many years, this cold 'Ross Desert' was considered to be sterile (Horowitz et al., 1972) because it lacks visible plant or animal life (apart from a few 
lichens). Micro-organisms found in soils (Boyd et al., 1966; Cameron, 1971) were thought to have come from human activities or to have arrived with coastal air as 'contaminants'. Microbial communities within the sandstone pore space were first reported by Friedmann \& Ocampo (1976). This cryptoendolithic ecosystem was studied more thoroughly by an international research group (Friedmann, 1980, 1985; Kappen et al., 1981; Hirsch et al., 1988; Nienow \& Friedmann, 1993). However, endemic microbial life in these hostile habitats and possible in situ activity has been supported by relatively few reports. Uydess \& Vishniac (1976) studied Dry Valley soil bacteria with transmission electron microscopy and suspected that these bacteria had grown locally. They also found possibly new, multiseptate bacterial forms. Kappen \& Friedmann (1983) measured active $\mathrm{CO}_{2}$ gas exchange of cryptoendolithic lichens, and P. Hirsch \& C. A. Gallikowski (unpublished results) observed growth of bacterial microcolonies on glass slides that had been exposed for one year to soils of Linnaeus Terrace (Asgard Range, $1600 \mathrm{~m}$ ).

Research on such soils and on the cryptoendolithic ecosystem in sandstone prompted attempts to isolate heterotrophic bacteria from rocks and surrounding soils. The use of oligotrophic media and mostly low incubation temperatures resulted in a wealth of different bacterial morphotypes many of which could be isolated (Hirsch et al., 1985, 1988; Gallikowski \& Hirsch, 1988). Some of these isolates were identified: Siebert \& Hirsch (1988) characterized 15 coccal bacteria, Dawid et al. (1988) demonstrated the presence, in soil samples, of psychrophilic myxobacteria, and Schumann et al. (1997) described Friedmanniella antarctica, a new actinomycete that came from a sandstone sample. Recently, Hymenobacter roseosalivarius was described as a relatively fast-growing bacterium from Ross Desert soils and sandstone samples (Hirsch et al., 1998). The present work concerns the description of four soil isolates as members of a new actinomycete genus and determines their phylogenetic position.

\section{METHODS}

Sampling, enrichment culture conditions and isolations. Soil samples were obtained aseptically by using sterile spoons and sterile Whirl-Pack plastic bags. All samples were stored and transported continuously frozen until studied in the Kiel laboratory. Oligotrophic medium PYGV (Staley, 1968) was used for enrichment cultures and isolations. It contained $\left(1^{-1}\right)$ : $250 \mathrm{mg}$ each of Bacto peptone (Difco), Bacto yeast extract and glucose, as well as $20 \mathrm{ml}$ Hutner's basal salts medium (Cohen-Bazire et al., 1957) and $10 \mathrm{ml}$ Vitamin solution no. 6 (Van Ert \& Staley, 1971). Enrichment culture and isolation conditions are listed in Table 1. Pure cultures were kept on PYGV agar slants or lyophilized or frozen at $-71{ }^{\circ} \mathrm{C}$.

Microscopy. For phase-contrast light microscopy and size measurements, preparations were made of young, liquidgrown cells on agar-coated slides (Pfennig \& Wagener,
1986). Motility was observed in hanging drop preparations. Cells for transmission electron microscopy were washed with $0.5 \mathrm{M}$ ammonium acetate, dried and $\mathrm{C} / \mathrm{Pt}$-shadowed at an angle of $35^{\circ}$, and observed with a Philips EM 300 electron microscope at $80 \mathrm{kV}$.

Physiological and biochemical characterizations. For physiological tests, the cells were incubated at $20^{\circ} \mathrm{C}$, but strain AA824 grew better at $9{ }^{\circ} \mathrm{C}$. Growth was determined as turbidity $\left(\mathrm{OD}_{620}\right)$ after homogenizing the aggregated cultures, or as protein increase using the Bio-Rad assay (Labrenz et al., 1998). All experiments were carried out in triplicate. Utilization of sugars or sugar alcohols $(1 \%, \mathrm{w} / \mathrm{v})$ was tested after 2-6 weeks cultivation on mineral salts medium as described by Shirling \& Gottlieb (1966). For the study of acid production from sugars or sugar alcohols, the strains were cultivated and evaluated as previously described (Gordon et al., 1974). Tests for hydrolysis of polymers (casein, gelatin, starch, hippurate, urea) followed directions of Gordon et al. (1974). DNase, lipase and phosphatase activities were tested as described by Smibert \& Krieg (1981). Degradation of xylan, arbutin, aesculin, adenine, hypoxanthine and xanthine was studied according to Horan \& Brodsky (1986). The following enzyme activities were tested as described in the literature: catalase (Smibert \& Krieg, 1981), cytochrome oxidase (Deibel \& Evans, 1960), sialidase (Potier et al., 1979), and type II restriction endonuclease (Whitehead \& Brown, 1985). Temperature tolerance for growth was studied with an aluminium temperature gradient block with four parallel borings for test tubes arranged in $1{ }^{\circ} \mathrm{C}$ steps between 0 and $35^{\circ} \mathrm{C}$. Evaluation of growth was done by turbidity measurement $\left(\mathrm{OD}_{620}\right)$ of homogenized cells. $\mathrm{NaCl}$ tolerance for growth was tested in triplicate cultures with medium PYGV to which up to $20 \%(\mathrm{w} / \mathrm{v})$ $\mathrm{NaCl}$ was added in steps of $0.5-1 \cdot 0 \%$. Growth was evaluated as turbidity after 2-8 weeks. For $\mathrm{pH}$ tolerance experiments, medium PYGV was adjusted to $\mathrm{pH} 2-13$ in steps of 0.5 units by adding $\mathrm{NaOH}$ or $\mathrm{HCl}$, respectively. Between $\mathrm{pH} 6$ and 8, the buffer capacity was increased by the

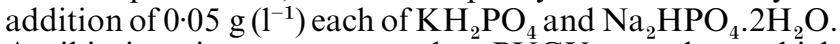
Antibiotic resistance was tested on $\mathrm{PYGV}$ agar plates which were inoculated with $100 \mu$ young culture. A 1-cm-diameter sterile filter disc was treated with $100 \mu$ antibiotic solution $\left(2 \mathrm{mg} \mathrm{ml} \mathrm{m}^{-1}\right)$ and placed onto the agar plate centre. The antibiotics chloramphenicol, kanamycin, penicillin $\mathrm{G}$, streptomycin and tetracycline were also added to liquid medium PYGV in concentrations of $10,50,100,500$ and $1000 \mu \mathrm{g}$ $\mathrm{ml}^{-1}$. Growth was evaluated after $10-30 \mathrm{~d}$ by protein determination and compared to growth in the absence of antibiotics. Nitrate reduction was tested according to Smibert \& Krieg (1981). Formation of $\mathrm{H}_{2} \mathrm{~S}$ from cystine was checked with lead acetate paper. Formation of ammonia from arginine or from peptone/yeast extract was tested with medium PYGV to which in the former case $3 \mathrm{~g}$ arginine $\mathrm{l}^{-1}$ was added (Skerman, 1967).

Chemotaxonomy. Cell wall preparations followed the rapid screening method of Schleifer \& Kandler (1972). The diamino acid type and isomer were identified with twodimensional TLC (Harper \& Davis, 1979). Molar ratios of cell wall amino acids were determined after derivatization with the PITC method (Pharmacia-LKB). Separation of derivatives occurred on a reverse-phase column $(25 \times 4.6 \mathrm{~cm}$; Bischoff) with Spherisorb RP18, $5 \mu \mathrm{m}$, as stationary phase. Retention time calculations and integration of peak areas were done with an IBM PS/2 model 30 computer using chromatography software (Nelson; model 2600 Rev. 5.0). For identification of cell wall sugars with the system of 
Table 1. Origin, enrichment and isolation conditions for the bacterial strains

The soil samples used for inoculation were collected aseptically from Linnaeus Terrace (1600 m, Asgard Range). Medium PYGV (Staley, 1968) was used throughout.

\begin{tabular}{|c|c|c|c|c|}
\hline & AA-802 & AA-824 & AA-825 & $\mathrm{AA}-826^{\mathrm{T}}$ \\
\hline \multicolumn{5}{|l|}{ Samples: } \\
\hline Number & $845 / 246$ & $845 / 247$ & $845 / 247$ & $845 / 247$ \\
\hline Depth $(\mathrm{cm})$ & $0-5$ & 5-7 & 5-7 & 5-7 \\
\hline $\mathrm{pH}(0 \cdot 1 \mathrm{M} \mathrm{KCl})$ & $5 \cdot 2$ & $5 \cdot 6$ & $5 \cdot 6$ & $5 \cdot 6$ \\
\hline \multicolumn{5}{|l|}{ Liquid enrichments: } \\
\hline Inoculum (g $\left.50 \mathrm{ml}^{-1}\right)$ & 3 & 3 & - & - \\
\hline Temperature $\left({ }^{\circ} \mathrm{C}\right)$ & 9 & 9 & - & - \\
\hline $\mathrm{pH}$ & $8 \cdot 0$ & $8 \cdot 0$ & - & - \\
\hline Light condition & Dark & Dark & - & - \\
\hline \multicolumn{5}{|l|}{ Agar direct inoculation: } \\
\hline Inoculum (g plate $\left.{ }^{-1}\right)$ & - & - & $0 \cdot 9$ & $0 \cdot 9$ \\
\hline Temperature $\left({ }^{\circ} \mathrm{C}\right)$ & - & - & 4 & 9 \\
\hline $\mathrm{pH}$ & - & - & $6 \cdot 5$ & $6 \cdot 5$ \\
\hline Light condition & - & - & Dark & Dim light* \\
\hline \multicolumn{5}{|l|}{ First subculture } \\
\hline After months & 12 & 12 & 5 & 1 \\
\hline
\end{tabular}

* Dim light: $2-4 \mu \mathrm{mol}$ photons $\mathrm{m}^{-2} \mathrm{~s}^{-1}$.

Staneck \& Roberts (1974), the cellulose-covered aluminium plates were developed three times. The plates were sprayed with an acid aniline-phthalate solution and heated to $105^{\circ} \mathrm{C}$.

Respiratory lipoquinones were extracted and purified as previously described (Collins et al., 1977). Their TLC separation followed the protocol of Collins et al. (1980) using reversed-phase thin-layer plates (HPTLC, RP18; Merck). Lipoquinone extracts $(1 \mathrm{ml})$ were quantified with a reversed-phase RP18 column with acetonitrile:tetrahydrofuran $(70: 30, \mathrm{v} / \mathrm{v})$ as mobile phase and the elution was done at $30^{\circ} \mathrm{C}$ at a flow rate of $1 \mathrm{ml} \mathrm{min}^{-1}$. MS (Finnegan Mat) at $200-230^{\circ} \mathrm{C}$ and with an ionization voltage of $70 \mathrm{eV}$ was used for identifying the quinones.

Polar lipids were separated and identified as described by Minnikin et al. (1984), using $6.6 \times 6.6 \mathrm{~cm}$ TLC silica gel $60 \mathrm{~F}_{254}$ plates (Merck). The solvent systems were chloroform:methanol:water $(65: 25: 4, \mathrm{v} / \mathrm{v}$, dimension 1$)$ and chloroform:acetic acid:methanol: water $(40: 7 \cdot 5: 6: 2$, $\mathrm{v} / \mathrm{v}$, dimension 2). Presence of free mycolic acids was tested according to Mordarska et al. (1972) with Nocardia asteroides IFAM 450 as positive and Amycolata saturnea IFAM 71 as negative controls. Tests for mycolic acids, which are only released by acid methanolysis, followed methods of Minnikin et al. (1975), with Mycobacterium phlei IFAM 437 as the positive control. The extraction, purification and methylation of fatty acids from $150-180 \mathrm{mg}$ lyophilized cell material followed methods of Eckhardt et al. (1979) and Hirsch et al. (1988). Fatty acid methyl esters were separated with a GC (Packard model 419 Becker) and an FFAP-CB-1.0 capillary column $(0.53 \mathrm{~mm} \times 25 \mathrm{~m}$; Macherey-Nagel) using a temperature programme of 190 $280^{\circ} \mathrm{C}\left(2 \cdot 2^{\circ} \mathrm{C} \min ^{-1}\right)$, and of $160-210^{\circ} \mathrm{C}\left(2^{\circ} \mathrm{C} \min ^{-1}\right)$, respectively, with nitrogen as the carrier gas $\left(7 \mathrm{ml} \mathrm{min}{ }^{-1}\right)$. The GC was equipped with an FID and Autolab Digital Integrator $6300 / 02$. Peaks were identified by comparison with analytical grade fatty acid methyl esters (Sigma).
Chemotaxonomic data for strain AA-825 were obtained following methods of Groth et al. (1996).

Determination of DNA base composition. Approximately $1 \mathrm{~g}$ wet cells was suspended in $0 \cdot 1 \mathrm{M}$ Tris $/ \mathrm{HCl} \mathrm{pH} 8 \cdot 0$, treated with $1 \mathrm{mg}$ lysozyme $\mathrm{ml}^{-1}$ (crystalline, $15000 \mathrm{U} \mathrm{mg}^{-1}$ ) and incubated for $30 \mathrm{~min}$ at $60{ }^{\circ} \mathrm{C}$. This was followed by the addition of proteinase $\mathrm{K}$ and SDS (both $0.5 \%$, w/v) until the viscosity reached a maximum. The SDS concentration was then raised to $2 \%(\mathrm{w} / \mathrm{v})$ and the resulting suspension was incubated for $20 \mathrm{~min}$ at $60{ }^{\circ} \mathrm{C}$ before $5.5 \mathrm{ml} 5 \mathrm{M} \mathrm{NaClO}_{4}$ was added (Holst, 1985). The DNA preparation was purified according to Marmur (1961) and the purity determined in a spectrophotometer 250 (Gilford) as described by Chandra \& Appel (1973). The base composition of nine replicates was determined as $T_{\mathrm{m}}$ using a Gilford spectrophotometer with a thermoprogrammed cuvette (Mandel \& Marmur, 1968).

$16 S$ rDNA sequence determination and analysis. The following strains were included in $16 \mathrm{~S}$ rDNA analyses: almost complete sequences were obtained for strains AA $-826^{\mathrm{T}}$ and AA- 825 while a stretch of 500 nucleotides of the $5^{\prime}$ terminus was determined for strains AA-802, -824 and $-826^{\mathrm{T}}$. Extraction of genomic DNA, PCR amplification of the 16S rDNA, and sequence analysis of the purified PCR products were as described previously (Rainey et al., 1996) and the sequence reactions were electrophoresed using a model 373A automatic DNA sequencer (Applied Biosystems). Sequences were aligned manually first with sequences of the class Actinobacteria and subsequently with those of the suborder Frankineae (Stackebrandt et al., 1997) published previously (Normand et al., 1996; Eppard et al., 1996; Rainey \& Stackebrandt, 1993; Rainey et al., 1993; Yoshimi et al., 1996). Similarity values were transformed into phylogenetic distance values that compensate for multiple substitutions at any given site in the sequence (Jukes \& Cantor, 1969). The algorithm of DeSoete (1983) (Maidak et al., 1997) and the neighbour-joining method contained in the PHYLIP package 
(Felsenstein, 1993) were used in the construction of phylogenetic dendrograms. All analyses were done on a SUN SparcII workstation.

Accession numbers. The accession numbers of the $16 \mathrm{~S}$ rDNAs of reference strains included in Fig. 3 were: Geodermatophilus obscurus subsp. obscurus DSM $43160^{\mathrm{T}}$, X92356; G. obscurus subsp. dictyosporus DSM 43161 ${ }^{\mathrm{T}}$, X92355; G. obscurus subsp. utahensis DSM 43162 ${ }^{\mathrm{T}}$, X92357; Sporichthya polymorpha DSM 46113 ${ }^{\mathrm{T}}$, X72377; Acidothermus cellulolyticus ATCC 43068 ${ }^{\mathrm{T}}$, X70494; Microsphaera multipartita JCM 9543, D50066; Frankia strain ArI4, L11307; strain A7S, X92360; strain G6, X92366; strain 4S, X92361; strain B-SWPS, X92363; strain 33S, X92362. The EMBL accession numbers of $16 \mathrm{~S}$ rDNA of Blastococcus aggregatus $\mathrm{DSM} 4725^{\mathrm{T}}$ and strain $\mathrm{AA}-826^{\mathrm{T}}$ are $\mathrm{Y} 18647$ and Y18646, respectively.

\section{RESULTS}

\section{Enrichments, isolation of bacteria and their morphology}

Oligotrophic liquid medium PYGV (50 ml) was adjusted to $\mathrm{pH} 8 \cdot 0$, inoculated with $3 \mathrm{~g}$ soil and incubated in the dark at $9^{\circ} \mathrm{C}$ for 12 months (Table 1). Also, PYGV agar plates $(\mathrm{pH} \mathrm{6.5)}$ were inoculated directly with soil particles $(0.9 \mathrm{~g})$ and incubated for $1-5$ months at 4 or $9^{\circ} \mathrm{C}$. A large variety of bacterial morphotypes multiplied (Hirsch et al., 1988). Among these were irregularly shaped, short rods or cocci with cross walls and often longitudinal septa. These cells produced slender buds (Fig. 1a, b) which eventually were motile after separation, although flagella were not found with the electron microscope. Corresponding morphotypes could be isolated from four additional soil samples and from a greenish powder inside a cracked sandstone sphere. Four isolates (AA$802,-824,-825$ and $-826^{\mathrm{T}}$ ) were similar, although their enrichments and/or isolations varied (Table 1). All

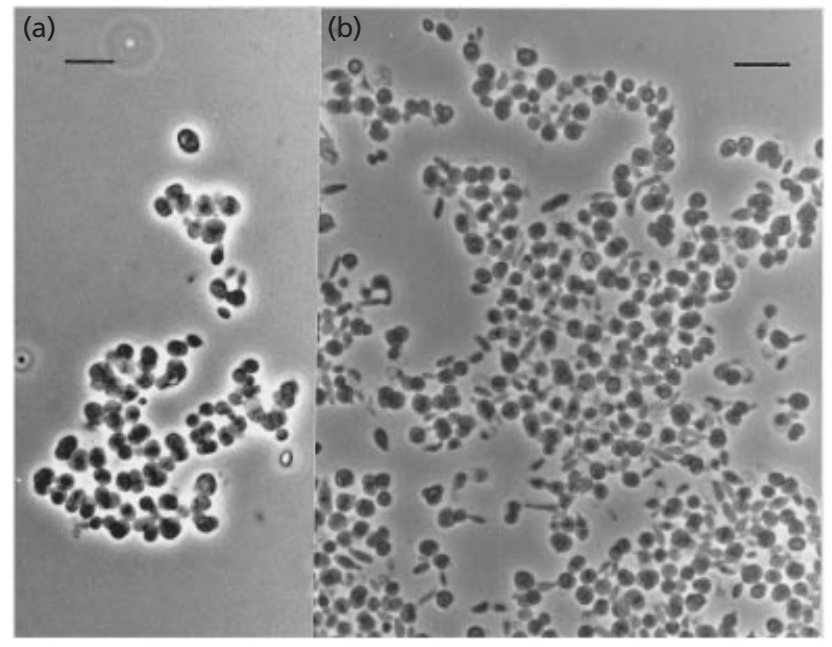

Fig. 1. Phase-contrast light micrographs. (a) Strain AA-802 grown $4 \mathrm{~d}$ on PYGV (pH 8.0) at $16^{\circ} \mathrm{C}$. (b) Strain AA-825 grown $6 \mathrm{~d}$ on PYGV agar at $16^{\circ} \mathrm{C}$. Bars, $5 \mu \mathrm{m}$.

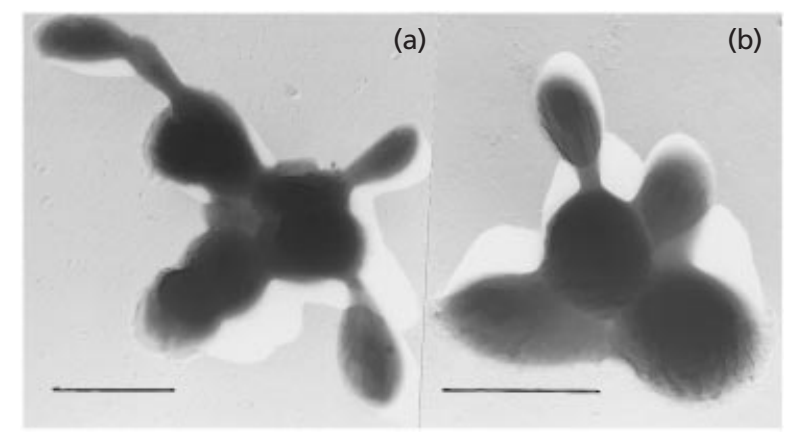

Fig. 2. Transmission electron micrographs, C/Pt shadowed. The isolates were grown on medium PYGV at $16^{\circ} \mathrm{C}$; bars, $2 \mu \mathrm{m}$. (a) Strain AA-824 after 39 d. (b) Strain AA-826 ${ }^{\top}$ after $13 \mathrm{~d}$.

were Gram-positive, short rods or cocci with a tendency to aggregate. Their cell size ranges were $1.0-2.8 \times 1.0-3.0 \mu \mathrm{m}$ with mean sizes of $1.7 \times 1.6-$ $1.9 \mu \mathrm{m}$. New cell formation was by cross and longitudinal wall growth as well as by budding with the production of motile swarmer cells, but in isolate AA825, motility could not be detected. Electron microscopy showed that new polar buds were often produced on still attached, small buds (Fig. 2a). Flagella were not found. Colonies were irregularly shaped, increasingly shiny, initially beige and later pinkish.

\section{Culture and growth characteristics}

All isolates grew well on medium PYGV, but growth was better on PYGV-8, containing peptone, yeast extract and glucose at the eightfold concentration of $2 \mathrm{~g} \mathrm{l}^{-1}$. Good growth was also observed on DSMZ medium 65 . Three of the strains grew at $0{ }^{\circ} \mathrm{C}$, they were facultatively psychrophilic and grew between 0 and 25-28 ${ }^{\circ} \mathrm{C}$. AA-824 was a true psychrophile with a growth optimum at $11-13^{\circ} \mathrm{C}$ and a maximum at $20{ }^{\circ} \mathrm{C}$. The temperature optima of the other three isolates were in the range of $19-22^{\circ} \mathrm{C}$ (Table 2$)$. There were some differences in the $\mathrm{pH}$ optimum for growth (Table 2), but all strains survived between $\mathrm{pH}$ 3-4 and 11-12. The maximum tolerance of $\mathrm{NaCl}$ varied between 2 and $8 \%(\mathrm{w} / \mathrm{v})$, and all strains grew well without $\mathrm{NaCl}$.

\section{Physiological and biochemical characteristics}

The four strains showed identical reactions in most physiological and biochemical tests. They exhibited catalase, cytochrome oxidase and phosphatase activities, but were negative for lipase (with triolein) and sialidase. Restriction endonuclease activity was found in AA-824 and AA-826 ${ }^{\mathrm{T}}$, but not in AA-802 or -825 . All isolates utilized D-glucose, D-galactose, lactose, sucrose or mannitol for growth, but did not grow with lyxose, cellobiose or inositol. The following carbon sources were used by some of the strains: L-arabinose, 
Table 2. Differences between the four Antarctic isolates

\begin{tabular}{|c|c|c|c|c|}
\hline Character & AA-802 & AA-824 & AA-825 & $\mathrm{AA}-826^{\mathrm{T}}$ \\
\hline Colony colour & Pale pink & Pale pink & Beige to grey & Pale pink \\
\hline \multicolumn{5}{|l|}{ C-utilization $(1 \%, \mathrm{w} / \mathrm{v})$ : } \\
\hline Maltose & + & + & - & $\mathrm{w}$ \\
\hline D-Mannose & + & + & - & $\mathrm{W}$ \\
\hline Melibiose & + & + & ND & - \\
\hline Fucose & - & - & ND & + \\
\hline D-Ribose & + & $\mathrm{w}$ & ND & - \\
\hline Sorbitol & + & $\mathrm{w}$ & ND & - \\
\hline L-Rhamnose & - & $\mathrm{w}$ & ND & w \\
\hline$N$-Acetylglucosamine & - & $\mathrm{W}$ & - & W \\
\hline \multicolumn{5}{|c|}{ Aerobic decarboxylations $(2 \%, \mathrm{w} / \mathrm{v})$ : } \\
\hline Benzoate & - & - & - & + \\
\hline Citrate & - & $\mathrm{w}$ & ND & + \\
\hline Glycolate & - & $\mathrm{W}$ & - & - \\
\hline Acid from glucose & + & - & ND & - \\
\hline \multicolumn{5}{|l|}{ Hydrolysis: } \\
\hline Aesculin & - & - & - & + \\
\hline Gelatin & - & - & + & - \\
\hline \multicolumn{5}{|l|}{ Temperature for growth $\left({ }^{\circ} \mathrm{C}\right)$ : } \\
\hline Maximum & 27 & 20 & 25 & 28 \\
\hline Optimum & $20-22$ & $11-13$ & 20 & $19-21$ \\
\hline pH optimum (growth) & $7 \cdot 5$ & $7 \cdot 5$ & $7 \cdot 5$ & $8 \cdot 0-8 \cdot 5$ \\
\hline pH tolerance (survival) & $4-12$ & $4-12$ & ND & $3-12$ \\
\hline $\mathrm{NaCl}$ maximum $(\%, \mathrm{w} / \mathrm{v})$ & 8 & 4 & 2 & 8 \\
\hline DNA $(\mathrm{mol} \% \mathrm{G}+\mathrm{C})$ & $69 \cdot 4 *$ & $68 \cdot 4^{*}$ & $69.9 \dagger$ & $69 \cdot 9 *$ \\
\hline
\end{tabular}

ND, Not determined; w, weak positive reaction.

* Determination as $T_{\mathrm{m}}$.

$\dagger$ Determination with HPLC (Groth et al., 1996).

erythritol and salicin. Except for isolate AA-824, all strains hydrolysed starch, but none of the strains hydrolysed adenine, hypoxanthine, xanthine, hippurate, cellulose, chitin, dextrin, xylan, arbutin or casein. Nitrogen sources used by all strains were peptone and yeast extract, AA-825 grew also with nitrate and ammonium. The isolates showed aerobic and anaerobic nitrate reduction. Ammonia formation from arginine, peptone or yeast extract was negative. The strains did not form $\mathrm{H}_{2} \mathrm{~S}$ from cystine or sulfate. They were sensitive to $10 \mu \mathrm{g} \mathrm{ml}^{-1}$ of ampicillin, carbenicillin, tobramycin or trimethoprim, and all strains showed sensitivity to $50 \mu \mathrm{g}$ lysozyme $\mathrm{ml}^{-1}$. Sensitivity to cystathionine, leucomycin, neomycin or tyrocidine was observed in some of the strains. The following organic acids were decarboxylated aerobically: fumarate, malate, succinate, pyruvate, glutarate and lactate. Differences among the strains (Table 2) concerned reactions to some carbon sources and tolerances of specific growth conditions.

\section{Chemotaxonomy}

The pattern of fatty acids is shown in Table 3. The major fatty acids in strains AA-802, $-824,-825$ and $826^{\mathrm{T}}$ were $\mathrm{n} 18: 1$, i16:0 and ai17:0 but some quan- titative differences were found in the case of cy19:0. The strains had MK-9 $\left(\mathrm{H}_{4}\right)$ and $\mathrm{MK}-8\left(\mathrm{H}_{4}\right)$ as major respiratory quinones (Table 4) and $\mathrm{MK}-9\left(\mathrm{H}_{6}\right)$ was found in small amounts, but not in AA-825. Mycolic acids were not present in any of the four strains. Polar lipids observed were diphosphatidylglycerol, phosphatidylethanolamine and phosphatidylinositol. Phosphatidylglycerol was also present but absent from AA-824 and -825 (Table 4). The cell walls contained meso-diaminopimelic acid, glutamate and alanine. Strains AA-824 and $-826^{\mathrm{T}}$ also had significant molar percentages of serine (Table 5). Cell wall hydrolysates of all strains contained galactose, glucose and ribose. DNA $\mathrm{G}+\mathrm{C}$ contents of the isolates ranged from 68 (AA-824) to $70\left(\right.$ AA- $826^{\mathrm{T}}$ ) $\mathrm{mol} \%$.

\section{Phylogenetic analysis}

Blastococcus aggregatus DSM $4725^{\mathrm{T}}$ and the Antarctic strains were subjected to $16 \mathrm{~S}$ rDNA analysis. $B$. aggregatus was found to be closely related to strain G1S from a Canadian landfill leachate (Eppard et al., 1996), while the nearest neighbours of B. aggregatus DSM $4725^{\mathrm{T}}$ were the three subspecies of Geodermatophilus obscurus (94.8-95.4\% similarity). Similarity 
Table 3. Fatty acids (\%) of the Antarctic isolates

Data $<1 \%$ were omitted.

\begin{tabular}{|lrrrc|}
\hline Fatty acid & AA-802 & AA-824 & AA-825* & AA-826 $^{\mathbf{T}}$ \\
\hline i14:0 & $1 \cdot 2$ & $1 \cdot 1$ & & $1 \cdot 9$ \\
n14:1 & $1 \cdot 5$ & $3 \cdot 5$ & $4 \cdot 2$ & $2 \cdot 6$ \\
n14:0 & $1 \cdot 7$ & $2 \cdot 4$ & $2 \cdot 5$ & $3 \cdot 4$ \\
i15:0 & $3 \cdot 3$ & $7 \cdot 0$ & $4 \cdot 8$ & $3 \cdot 3$ \\
ai15:0 & $5 \cdot 3$ & $6 \cdot 5$ & $2 \cdot 7$ & $7 \cdot 8$ \\
n15:0 & $1 \cdot 4$ & $1 \cdot 8$ & $1 \cdot 5$ & $2 \cdot 1$ \\
i15:1 & & & $6 \cdot 3$ & \\
n15:1 & & & $1 \cdot 2$ & \\
i16:0 & $18 \cdot 8$ & $10 \cdot 9$ & $9 \cdot 8$ & $13 \cdot 8$ \\
n16:1 & $5 \cdot 3$ & $5 \cdot 6$ & $10 \cdot 0$ & $6 \cdot 2$ \\
n16:0 & $5 \cdot 7$ & $5 \cdot 7$ & $6 \cdot 4$ & $7 \cdot 9$ \\
i16:1 & & & $5 \cdot 0$ & \\
i17:0 & & & & \\
ai17:0 & $12 \cdot 7$ & $13 \cdot 6$ & $12 \cdot 2$ & $9 \cdot 2$ \\
n17:1 & & & $1 \cdot 9$ & \\
n18:1 & $17 \cdot 1$ & $23 \cdot 8$ & $19 \cdot 8$ & $21 \cdot 4$ \\
n18:0 & $1 \cdot 7$ & $2 \cdot 7$ & & $2 \cdot 2$ \\
n19:0 & & $1 \cdot 1$ & $3 \cdot 5$ & \\
cy19:0 & $10 \cdot 1$ & $4 \cdot 9$ & $3 \cdot 4$ & $8 \cdot 5$ \\
Unidentified & $11 \cdot 6$ & $6 \cdot 4$ & & $7 \cdot 0$ \\
Total & $\mathbf{9 7 \cdot 4}$ & $\mathbf{9 7 \cdot 0}$ & $\mathbf{9 5} \cdot \mathbf{2}$ & $\mathbf{9 7 \cdot 3}$ \\
\hline
\end{tabular}

* Data obtained by capillary GC according to Groth et al. (1996).

Table 4. Respiratory quinones (\%) and phospholipids of the Antarctic isolates

\begin{tabular}{|c|c|c|c|c|}
\hline & \multicolumn{3}{|c|}{ AA-802 AA-824 AA-825 } & \multirow[t]{2}{*}{$\mathrm{AA}-826^{\mathrm{T}}$} \\
\hline Respiratory qu & & & & \\
\hline MK-9 $\left(\mathrm{H}_{4}\right)$ & 87 & 88 & 69 & 87 \\
\hline MK-8 $\left(\mathrm{H}_{4}\right)$ & 9 & 10 & 9 & 12 \\
\hline MK-9 $\left(\mathrm{H}_{6}\right)$ & 4 & 2 & - & 2 \\
\hline \multicolumn{5}{|c|}{ Phospholipids:* } \\
\hline DPG & + & + & + & + \\
\hline PG & + & - & - & + \\
\hline PE & + & + & + & + \\
\hline PI & + & + & + & + \\
\hline PL 1 & - & - & + & - \\
\hline PL 2 & - & + & - & - \\
\hline
\end{tabular}

*DPG, Diphosphatidylglycerol; PG, phosphatidylglycerol; PE, phosphatidylethanolamine; PI, phosphatidylinositol; PL 1, unidentified phospholipid 1; PL 2, unidentified phospholipid 2.

values obtained for 500 nucleotides from the $5^{\prime}$ terminus revealed a high interstrain relationship ( $>99.5 \%$ similarity), and consequently almost complete sequences were generated from only two strains, AA- $826^{T}$ and -825 . Their sequences were $99.9 \%$ similar. With similarity values ranging between 96.9
Table 5. Cell wall amino acids of three Antarctic isolates observed with TLC and their molar ratios to glutamic acid as determined with HPLC

Ala, Alanine; Glu, glutamic acid; mDAP, mesodiaminopimelic acid; Gly, glycine; Ser, serine; Arg, arginine; Leu, leucine.

\begin{tabular}{|lccccccc|}
\hline Isolate & Ala & Glu & mDAP & Gly & Ser & Arg & Leu \\
\hline AA-802 & 1.59 & $1 \cdot 00$ & 0.78 & 0.52 & $0 \cdot 01$ & $0 \cdot 13$ & $0 \cdot 40$ \\
AA-824 & 1.98 & 1.00 & 0.73 & 0.42 & $0 \cdot 26$ & $0 \cdot 17$ & $0 \cdot 19$ \\
AA-826 & 1.75 & 1.00 & 0.85 & 0.66 & 0.56 & $0 \cdot 33$ & $0 \cdot 15$ \\
\hline
\end{tabular}

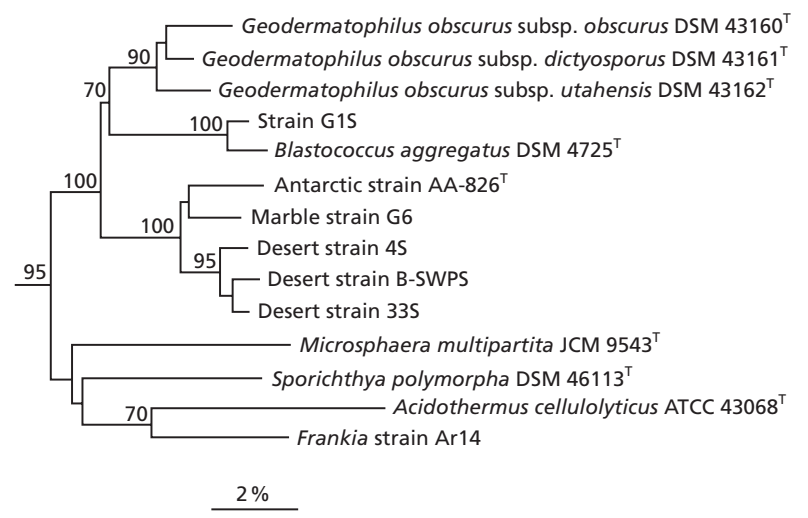

Fig. 3. Phylogenetic tree showing the position of isolate $A A-$ $826^{\top}$ within the suborder Frankineae, based upon 16S rDNA analysis (DeSoete, 1983; Jukes \& Cantor, 1969). The sequence of members of Micrococcineae served as an outgroup sequence. Numbers within the dendrogram indicate the percentages of the branching order in 500 bootstrapped trees. Bar, 2 nucleotide substitutions per 100 nucleotides.

and $97.5 \%$ the nearest phylogenetic neighbours of the AA strains were undescribed actinomycete strains isolated from dry soil and monument surfaces (Eppard et al., 1996). These latter strains, for which a formal description has not yet been given, were recently identified as belonging to a novel phylogenetic cluster within the family Geodermatophilaceae in which they formed a 'cluster II' (Eppard et al., 1996). The phylogenetic relatedness of strain AA $-826^{\mathrm{T}}$ and cluster II is supported by high bootstrap values (Fig. 3). Members of this cluster showed an equidistant relationship to members of the genus Geodermatophilus, and to the Blastococcus-related strain G1S lineage (94-96\% similarity).

\section{DISCUSSION}

The Antarctic soil isolates were phenotypically very similar and had nearly identical DNA base ratios. Some differences (Table 2) in the carbon utilization spectrum, in the temperature and $\mathrm{pH}$ optima, and maximum $\mathrm{NaCl}$ tolerance could be due to their 
Table 6. Differential characteristics of Modestobacter multiseptatus gen. nov., sp. nov. strain AA-826 ${ }^{\top}$ and related Gram-positive bacteria

Strains: 1, Geodermatophilus obscurus subsp. obscurus DSM 43160 $;$; , strain G1S; 3, Blastococcus aggregatus DSM 4725 ; 4, Antarctic isolate AA-826 ${ }^{\mathrm{T}}$; 5, strains 4S, B-SWPS, 33S; 6, Microsphaera multipartita JCM $9543^{\mathrm{T}}$.

\begin{tabular}{|c|c|c|c|c|c|c|}
\hline Characteristic & $1^{*}$ & $2 *$ & $3 \dagger$ & 4 & $5^{*}$ & $6 \div$ \\
\hline Cell shape & Cocci to cuboids & $\begin{array}{l}\text { Cocci, rods, } \\
\text { filaments }\end{array}$ & Cocci, rods, vibrios & Cocci, rods & $\begin{array}{l}\text { Cocci, rods, } \\
\text { filaments }\end{array}$ & Cocci, never rods \\
\hline Cell diameter $(\mu \mathrm{m})$ & $0 \cdot 5-2 \cdot 0$ & ca. $0 \cdot 5-1 \cdot 0 \S$ & $0 \cdot 3-1 \cdot 5(2 \cdot 5)$ & $1 \cdot 0-2 \cdot 8(1 \cdot 7)$ & ca. $0 \cdot 4-1 \cdot 2 \S$ & $0 \cdot 8-3 \cdot 0$ \\
\hline Bud formation & $\pm \|$ & + & + & + & + & - \\
\hline Motility & \pm & - & + & + & - & - \\
\hline Flagellar insertion & Polar & & Subpolar & & & \\
\hline Colony colour & Brown/black & Orange to pink & Pink & Pale pink & Orange to pink & Cream-coloured \\
\hline $\mathrm{O}_{2}$ requirement & Aerobic & Aerobic & Aerobic/microaerophilic & Aerobic & Aerobic & Aerobic \\
\hline \multicolumn{7}{|l|}{$\mathrm{NaCl}$ tolerance } \\
\hline Growth at $3 \%$ & - & + & + & + & + & + \\
\hline Growth at $5 \%$ & - & + & + & + & - & \\
\hline Growth at $6 \%$ & - & + & - & + & - & + \\
\hline Temp. optimum $\left({ }^{\circ} \mathrm{C}\right)$ & $24-28 \|$ & 28 & 25 & $19-21$ & 28 & 25 \\
\hline Range for growth $\left({ }^{\circ} \mathrm{C}\right)$ & $18-37$ & $18-37$ & $3-40$ & $0-28$ & $18-37$ & $10-35$ \\
\hline $\mathrm{pH}$ optimum & & & $7 \cdot 0$ & $8 \cdot 0-8 \cdot 5$ & & $7 \cdot 0$ \\
\hline Range for growth & & & & $4 \cdot 0-9 \cdot 5$ & & $5 \cdot 0-9 \cdot 0$ \\
\hline Hydrolysis of starch & + & + & - & + & + & + \\
\hline Gelatin liquefaction & $\pm \|$ & - & - & - & + & \\
\hline Casein utilization & - & - & & - & + & \\
\hline \multicolumn{7}{|l|}{ Carbon sources: } \\
\hline Ethanol & - & - & w & - & - & + \\
\hline D-Glucose & + & & - & + & & + \\
\hline Acetate & & & - & + & & - \\
\hline Citrate & & & - & + & & - \\
\hline Nitrate reduction & w & & w & - & & \\
\hline Major menaquinone & MK-9 $\left(\mathrm{H}_{4}\right) \uparrow$ & & MK-9 $\left(\mathrm{H}_{4}\right)$ ฯ & MK-9 $\left(\mathrm{H}_{4}\right) \oplus$ & & MK- $8\left(\mathrm{H}_{4}\right)$ \\
\hline Major fatty acids ( \%) & & & & n18:1 (21.4); & & i16:0 (19.7); i15:0 (15.7) \\
\hline & & & & i16:0 (13.8) & & \\
\hline DNA $(\mathrm{mol} \% \mathrm{G}+\mathrm{C})$ & $72 \cdot 9-74 \cdot 6$ ( & & & $69 \cdot 9$ & & 67.5 \\
\hline
\end{tabular}

* Data from Eppard et al. (1996).

$\dagger$ Data from Ahrens \& Moll (1970).

† Data from Yoshimi et al. (1996).

$\S$ Measurements determined from micrographs in Eppard et al. (1996).

|| Data from Bergey's Manual of Determinative Bacteriology, 8th edn (Buchanan \& Gibbons, 1974).

- Data from Normand et al. (1996).

$\mathrm{w}$, Weak but positive reaction.

different origin and enrichment conditions (Table 1). Fatty acid analysis (Table 3 ) indicated that AA-802, $-824,-825$ and $-826^{\mathrm{T}}$ were similar with respect to their major fatty acids, n18:1, i16:0 and ai17:0. The phospholipid analysis (Table 4) showed some similarities between strains AA-824 and -825.

Strain AA $-826^{\mathrm{T}}$ best represents this phylogenetically and phenotypically highly related group of Antarctic soil isolates. Phylogenetic analysis clearly indicates that this strain is a member of the family Geodermatophilaceae. Its position within the radiation of type species of four genera and a representative Frankia strain demonstrates the Antarctic strain group to be closely related to the genus Geodermatophilus and Blastococcus aggregatus (Fig. 3). Its equidistant position to these two is indicative of a novel genus, and the proposal for a new genus is supported by morphological, biochemical and chemotaxonomic properties which distinguish AA- $826^{\mathrm{T}}$ from the established genera of the family (Table 6).
The Antarctic strains are closely related to isolates from Greek marble, limestone from the Negev Desert and rock varnish from the Mojave Desert that were previously analysed (Eppard et al., 1996). Some of the inter-strain 16S rDNA similarity values $(97 \cdot 2-97 \cdot 9 \%$ ) are as low as those found for these isolates and strains AA- $826^{\mathrm{T}}$ and $-825(96 \cdot 9-97 \cdot 5 \%)$. Therefore, strains AA-802, $-824,-825$ and $-826^{\mathrm{T}}$ are considered to represent a new genus, and the marble strain G6 as well as desert strains $4 \mathrm{~S}, 33 \mathrm{~S}$ and B-SWPS may be additional species of the same genus. However, these latter strains until now have only been characterized by morphology, pigmentation, some growth characteristics and few biochemical properties. Chemotaxonomy and extensive metabolic traits that would permit their description as novel species have not yet been reported.

The new genus is named Modestobacter, and AA- $826^{\mathrm{T}}$ is the type strain for the type species, named Modestobacter multiseptatus. 


\section{Description of Modestobacter gen. nov.}

Modestobacter (Mo.des.to.bac'ter. L. adj. modestus modest, humble; bacter the equivalent of Gr. neut. n. baktron a rod or staff; M. L. masc. n.. Modestobacter a rod with modest growth requirements).

Gram-positive short rods or cocci with a tendency to remain aggregated. Cells $1 \cdot 0-2 \cdot 8 \times 1 \cdot 0-3 \cdot 0 \mu \mathrm{m}$, showing cross and longitudinal wall growth and multiplying by budding and swarmer formation. Colonies are irregularly shaped, shiny, beige to pink. Does not form spores. Aerobic heterotroph, growing on oligotrophic medium PYGV or on DSMZ medium 65. Growth occurs between $0-5{ }^{\circ} \mathrm{C}$ and $20-28{ }^{\circ} \mathrm{C}$; a psychrophilic strain grows optimally at $11-13{ }^{\circ} \mathrm{C}$. pH tolerance for survival lies between $\mathrm{pH} 3-4$ and 11-12. Positive for catalase, cytochrome oxidase and phosphatase. Some strains show restriction endonuclease activity. Carbon sources utilized for growth are: Dglucose, D-galactose, lactose, sucrose and mannitol. Compounds not hydrolysed are: adenine, hypoxanthine, xanthine, hippurate, cellulose, chitin, dextrin, xylan, arbutin or casein. All strains utilize peptone or yeast extract as nitrogen source and reduce nitrate aerobically or anaerobically. Ammonia is not formed from arginine, peptone or yeast extract. $\mathrm{H}_{2} \mathrm{~S}$ is not formed from cystine or sulfate. Sensitive to lysozyme. Major fatty acids are n18:1, i16:0 and ai17:0. Major respiratory quinones are $\mathrm{MK}-9\left(\mathrm{H}_{4}\right)$ and $\mathrm{MK}-8\left(\mathrm{H}_{4}\right)$; polar lipids of all isolates are diphosphatidylglycerol, phosphatidylethanolamine and phosphatidylinositol. The cell wall contains meso-diaminopimelic acid, glutamate, alanine and glycine as well as galactose, glucose and ribose. The type species for the genus is Modestobacter multiseptatus.

\section{Description of Modestobacter multiseptatus sp. nov.}

Modestobacter multiseptatus (mul.ti.sep.ta'tus. L. masc. n. multus much; L. adj. septatus fenced; M.L. masc. adj. multiseptatus much fenced, with many septa).

Cell sizes vary $(1.0-2.8 \times 1.0-3.0 \mu \mathrm{m})$ with a mean size of $1.7 \times 1.6-1.9 \mu \mathrm{m}$. Slender buds may become motile. Colonies irregular, beige to skin-coloured and pinkish. Does not utilize fructose, xylose or trehalose. Utilization of maltose, mannose, melibiose, fucose, ribose, rhamnose, sorbitol or $\mathrm{N}$-acetylglucosamine are variable. Growth occurs on succinate or malate. Aerobic decarboxylation of benzoate, citrate, acetate or glycolate is variable. Reactions for amylase and type II restriction endonuclease are positive. Growth occurs at $0-5{ }^{\circ} \mathrm{C}$ with a maximum at $20-28{ }^{\circ} \mathrm{C}$. pH optimum for growth is 7.5-8.5. Major fatty acids are n18:1, ai17:0 and i16:0. The main respiratory quinone is MK-9 $\left(\mathrm{H}_{4}\right)$, but MK-8 $\left(\mathrm{H}_{4}\right)$ and MK-9 $\left(\mathrm{H}_{6}\right)$ may occur in small amounts. Presence of phosphatidylglycerol is variable. The DNA $\mathrm{G}+\mathrm{C}$ content is $68-70 \mathrm{~mol} \%$. Other characteristics are as for the genus. Origin: Antarctic surface soil from Linnaeus Terrace $(1600 \mathrm{~m})$ of Asgard Range/Transantarctic Mountains. The type strain, AA-826 ${ }^{\mathrm{T}}$, was deposited in the DSMZ under accession number DSM $44406^{\mathrm{T}}$. Additional isolates of Modestobacter multiseptatus are strains AA-825 (= DSM 44405), -824 (= DSM 44404) and -802 (= DSM 44402).

\section{ACKNOWLEDGEMENTS}

Skilful technical assistance of B. Hoffmann and M. Beese is gratefully acknowledged. We thank B. Tindall (Braunschweig) for helpful discussions and H. Völker (Kiel) for work with the electron microscope. We are especially grateful to the US National Science Foundation (Polar Program) and E. I. Friedmann (Tallahassee, Florida) for generous support during three Antarctic expeditions and a personal grant to E. I. Friedmann (DPP83-14180). The Deutsche Forschungsgemeinschaft (DFG) supported one of us (P.H.) with travel and research grants (Hi 68/13-1 to -5).

\section{REFERENCES}

Ahrens, R. \& Moll, G. (1970). Ein neues knospendes Bakterium aus der Ostsee. Arch Mikrobiol 70, 243-265.

Behling, R. E. (1971). Chemical weathering in Wright Valley. Antarct J US 10, 214-215.

Boyd, W. L., Staley, J. T. \& Boyd, J. W. (1966). Ecology of soil microorganisms of Antarctica. In Antarctic Soils and SoilForming Processes, vol. 8, Antarctic Research Series, pp. 125-159. Washington: American Geophysical Union.

Buchanan, R. E. \& Gibbons, N. E. (editors) (1974). Bergey's Manual of Determinative Bacteriology, 8th edn. Baltimore: Williams \& Wilkins.

Cameron, R. E. (1971). Antarctic soil microbial and ecological investigations. In Research in Antarctica, vol. 93, pp. 137-190. Edited by L. O. Quam \& H. D. Porter. Washington, DC: American Association for the Advancement of Science.

Chandra, P. \& Appel, W. (1973). Methoden der Molekularbiologie, pp. 29-32. Stuttgart: Fischer Verlag.

Cohen-Bazire, G., Sistrom, W. R. \& Stanier, R. Y. (1957). Kinetic studies of pigment synthesis by non-sulfur purple bacteria. $J$ Cell Physiol 49, 25-68.

Collins, M. D., Pírouz, T., Goodfellow, M. \& Minnikin, D. E. (1977). Distribution of menaquinones in actinomycetes and corynebacteria. J Gen Microbiol 100, 221-230.

Collins, M. D., Shah, H. N. \& Minnikin, D. E. (1980). A note on the separation of natural mixtures of bacterial menaquinones using reverse-phase thin-layer chromatography. J Appl Bacteriol 48, 277-282.

Dawid, W., Gallikowski, C. A. \& Hirsch, P. (1988). Psychrophilic myxobacteria from antarctic soils. Polarforsch 58, 271-278.

Deibel, R. H. \& Evans, J. B. (1960). Modified benzidine test for the detection of cytochrome-containing respiratory systems in microorganisms. J Bacteriol 79, 356-360.

DeSoete, G. (1983). A least squares algorithm for fitting additive trees to proximity data. Psychometrika 48, 621-626.

Eckhardt, F. E. W., Roggentin, P. \& Hirsch, P. (1979). Fatty acid composition of various hyphal budding bacteria. Arch Microbiol 120, 81-85.

Eppard, M., Krumbein, W. E., Koch, C., Rhiel, E., Staley, J. T. \& Stackebrandt, E. (1996). Morphological, physiological and molecular characterization of actinomycetes isolated from dry soil, rocks and monument surfaces. Arch Microbiol 166, 12-22. 
Felsenstein, J. (1993). PHYLIP (phylogenetic inference package) version 3.5.1. Department of Genetics, University of Washington, Seattle, WA, USA.

Friedmann, E. I. (1980). Endolithic microbial life in hot and cold deserts. Origin of Life 10, 223-235.

Friedmann, E.I. (1985). Field studies of antarctic cryptoendolithic microbial ecosystems, 1984-1985. Antarct J US 19, $178-180$

Friedmann, E. I. \& Ocampo, R. (1976). Endolithic blue-green algae in the dry valleys: primary producers and the antarctic desert ecosystem. Science 193, 1247-1249.

Gallikowski, C. A. \& Hirsch, P. (1988). Preliminary characterization and identification of 1984/85 continental antarctic soil microorganisms of Linnaeus Terrace (altitude $1600 \mathrm{~m}$; McMurdo Dry Valleys). Polarforsch 58, 93-101.

Gordon, R. E., Barnett, D. A., Handerhan, J. E. \& Hor-Nay Pang, C. (1974). Nocardia coeliaca, Nocardia autotrophica, and the nocardin strain. Int J Syst Bacteriol 24, 54-63.

Groth, I., Schumann, P., Weiss, N., Martin, K. \& Rainey, F. A. (1996). Agrococcus jenensis gen. nov., sp. nov., a new genus of actinomycetes with diaminobutyric acid in the cell wall. Int $J$ Syst Bacteriol 46, 234-239.

Harper, J. J. \& Davis, G. H. G. (1979). Two-dimensional thin-layer chromatography for amino acid analysis of bacterial cell walls. Int J Syst Bacteriol 29, 56-58.

Hirsch, P., Gallikowski, C. A. \& Friedmann, E. I. (1985). Microorganisms in soil samples from Linnaeus Terrace, southern Victoria Land: preliminary observations. Antarct J US 1985 Review, 183-186.

Hirsch, P., Hoffmann, B., Gallikowski, C. A., Mevs, U., Siebert, J. \& Sittig, M. (1988). Diversity and identification of heterotrophs from antarctic rocks of the McMurdo Dry Valleys (Ross Desert). Polarforsch 58, 261-269.

Hirsch, P., Ludwig, W., Hethke, C., Sittig, M., Hoffmann, B. \& Gallikowski, C. A. (1998). Hymenobacter roseosalivarius gen. nov., sp. nov. from continental antarctic soils and sandstone: bacteria of the Cytophaga/Flavobacterium/Bacteroides line of phylogenetic descent. Syst Appl Microbiol 21, 374-383.

Holst, U. (1985). Versuche zum Aufschluss bzw zur Lyse von hyphen- und knospentragenden Bakterien durch Mikroorganismen, Enzyme oder andere Methoden. MSc thesis, University of Kiel, pp. 35-41.

Horan, A. C. \& Brodsky, B. (1986). Micromonospora rosaria $\mathrm{sp.}$ nov., rev., the rosaramicin producer. Int J Syst Bacteriol 36, 478-480.

Horowitz, N. H., Cameron, R. E. \& Hubbard, J. S. (1972). Microbiology of the dry valleys of Antarctica. Science 176, 242-245. Jukes, T. H. \& Cantor, C. R. (1969). Evolution of protein molecules, pp. 21-132. In Mammalian Protein Metabolism. Edited by H. N. Munro. New York: Academic Press.

Kappen, L. \& Friedmann, E. I. (1983). Ecophysiology of lichens in the dry valleys of Southern Victoria Land, Antarctica. 2. $\mathrm{CO}_{2}$ gas exchange in cryptoendolithic lichens. Polar Biol 1, 227-232.

Kappen, L., Friedmann, E. I. \& Garty, J. (1981). Ecophysiology of lichens in the dry valleys of Southern Victoria Land, Antarctica. 1. Microclimate of the endolithic lichen habitat. Flora 171, 216-235

Labrenz, M., Collins, M. D., Lawson, P. A., Tindall, B. J., Braker, G. \& Hirsch, P. (1998). Antarctobacter heliothermus gen. nov., sp. nov., a budding bacterium from hypersaline and heliothermal Ekho Lake. Int J Syst Bacteriol 48, 1363-1372.
McKay, C. P. \& Friedmann, E. I. (1985). The cryptoendolithic microbial environment in the antarctic cold desert : temperature variations in nature. Polar Biol 3, 19-25.

Maidak, B. L., Larsen, N., McCaughey, M. J., Overbeek, R., Olsen, G. J. \& Woese, C. R. (1997). The ribosomal database project. Nucleic Acids Res 25, 109-111.

Mandel, M. \& Marmur, J. (1968). Use of ultraviolet absorbancetemperature profile for detecting guanidine plus cytosine content of DNA. In Methods in Enzymology 12B, pp. 195-206. Edited by L. Grossman \& K. Moldave. London: Academic Press.

Marmur, J. (1961). A procedure for the isolation of deoxyribonucleic acid from microorganisms. J Mol Biol 3, 208-218.

Minnikin, D. E., Alshamaony, L. \& Goodfellow, M. (1975). Differentiation of Mycobacterium, Nocardia and related taxa by thin-layer chromatographic analysis of whole- organism methanolysates. J Gen Microbiol 88, 200-204.

Minnikin, D. E., Minnikin, S. M., O’Donnell, A. G. \& Goodfellow, M. (1984). Extraction of mycobacterial mycolic acids and other long-chain compounds by an alkaline methanolysis procedure. $J$ Microbial Methods 2, 243-249.

Mordarska, H., Mordarski, M. \& Goodfellow, M. (1972). Chemotaxonomic characters and classification of some nocardioform bacteria. J Gen Microbiol 71, 77-86.

Nienow, J. A. \& Friedmann, E. I. (1993). Terrestrial lithophytic (rock) communities. In Antarctic Microbiology, pp. 343-412. Edited by E. I. Friedmann. New York: Wiley-Liss.

Normand, P., Orso, S., Cournoyer, B., Jeannin, P., Chapelon, C., Dawson, J., Evtushenko, L. \& Misra, A. K. (1996). Molecular phylogeny of the genus Frankia and related genera and emendation of the family Frankiaceae. Int J Syst Bacteriol 46, $1-6$.

Pfennig, N. \& Wagener, S. (1986). An improved method of preparing wet mounts for photomicrographs of microorganisms. J Microbiol Methods 4, 303-306.

Potier, M., Mameli, L., Blisle, M., Dallaire, L. \& Melanon, S. B. (1979). Fluorometric assay of neuraminidase with a sodium (4methylumbelliferyl-D- $N$-acetylneuraminate) substrate. Annal Biochem 94, 287-296.

Rainey, F. A. \& Stackebrandt, E. (1993). Phylogenetic evidence for the classification of Acidothermus cellulolyticus into the subphylum of actinomycetes. FEMS Microbiol Lett 108, 27-30.

Rainey, F. A., Schumann, P., Prauser, H., Toalster, R. \& Stackebrandt, E. (1993). Sporichthya polymorpha represents a novel line of descent within the order Actinomycetales. FEMS Microbiol Lett 109, 263-269.

Rainey, F. A., Ward-Rainey, N., Kroppenstedt, R. M. \& Stackebrandt, E. (1996). The genus Nocardiopsis represents a phylogenetically coherent taxon and a distinct actinomycete lineage: proposal of Nocardiopsaceae fam. nov. Int J Syst Bacteriol 46, 1088-1092.

Schleifer, K. H. \& Kandler, O. (1972). Peptidoglycan types of bacterial cell walls and their taxonomic implications. Bacteriol Rev 36, 407-477.

Schumann, P., Prauser, H., Rainey, F. A., Stackebrandt, E. \& Hirsch, P. (1997). Friedmanniella antarctica gen. nov., sp. nov., an LL-diaminopimelic acid-containing actinomycete from antarctic sandstone. Int J Syst Bacteriol 47, 278-283.

Shirling, E. B. \& Gottlieb, D. (1966). Methods for the description of Streptomyces species. Int J Syst Bacteriol 16, 313-340.

Siebert, J. \& Hirsch, P. (1988). Characterization of 15 selected coccal bacteria isolated from antarctic rock and soil samples 
from the McMurdo-Dry Valleys (South Victoria Land). Polar Biol 9, 37-44.

Skerman, V. B. D. (1967). A Guide to the Identification of the Genera of Bacteria with Methods and Digests of Generic Characteristics, 2nd edn, 303 pp. Baltimore: Williams \& Wilkins.

Smibert, R. M. \& Krieg, N. R. (1981). General characterization. In Manual of Methods for General Bacteriology, pp. 412-422. Edited by P. Gerhardt. Washington, DC: American Society for Microbiology.

Stackebrandt, E., Rainey, F. A. \& Ward-Rainey, N. (1997). Proposal for a hierarchic classification system, Actinobacteria classis nov. Int J Syst Bacteriol 47, 479-491.

Staley, J. T. (1968). Prosthecomicrobium and Ancalomicrobium, new prosthecate freshwater bacteria. J Bacteriol 95, 19211942.
Staneck, J. L. \& Roberts, G. D. (1974). Simplified approach to identification of aerobic actinomycetes by thin-layer chromatography. Appl Microbiol 28, 226-231.

Uydess, J. L. \& Vishniac, W. V. (1976). Electron microscopy of antarctic soil bacteria. In Extreme Environments, pp. 29-56. Edited by M. R. Heinrich. London: Academic Press.

Van Ert, M. \& Staley, J. T. (1971). Gas-vacuolated strains of Microcyclus aquaticus. J Bacteriol 108, 236-240.

Whitehead, P. R. \& Brown, N. L. (1985). A simple and rapid procedure for screening bacteria for type II restriction endonucleases: enzymes in Aphanothece halophytica. Arch Microbiol 143, 74-81.

Yoshimi, Y., Hiraishi, A. \& Nakamura, K. (1996). Isolation and characterization of Microsphaera multipartita gen. nov., sp. nov., a polysaccharide-accumulating Gram-positive bacterium from activated sludge. Int J Syst Bacteriol 46, 519-525. 